\title{
TRAFFIC NOISE POLLUTION DOES NOT INFLUENCE HABITAT SELECTION IN THE ENDANGERED LITTLE BUSTARD
}

\section{LA CONTAMINACIÓN SONORA DEBIDA AL TRÁFICO RODADO NO INFLUYE EN LA SELECCIÓN DE HÁBITAT DEL SISÓN COMÚN}

\author{
Irene Martínez-Marivela ${ }^{1}$, Manuel B. Morales ${ }^{1}{ }^{*}$, \\ Carlos Iglesias-Merchán ${ }^{2,3}$, María Paula Delgado ${ }^{1}$, Rocío TARJuelo ${ }^{1,4}$ \\ and Juan TrABA ${ }^{1}$
}

\begin{abstract}
SUMmARY.- Traffic noise is an associated effect of roads, potentially impacting wildlife. In the case of birds, it may alter spatial distribution, behavioural responses and physiological status, frequently masking the acoustic signals of conspecifics and predators. We analyse how road traffic noise affects habitat selection of Little Bustard males during the breeding season, when they produce brief territorial snort calls. The study site is in a typical agrarian area in central Spain, markedly affected by traffic noise. A noise map was built using specific environmental noise modelling software. The habitat in the territories of 26 individually-recognisable males (62\% of the male population in the study year) was characterised in relation to noise levels, agrarian substrate composition and distance to nearest males. Habitat selection models were performed using MaxEnt, and an averaged model of the first 20 significant ones was generated. The noise map revealed high noise pollution levels for the whole study area (range: 50.13-62.35 dB). Distance to the nearest male was the most important variable in habitat selection models, so that as distance increased suitability decreased, while the effect of traffic noise was nearly negligible. This lack of traffic noise effect on the habitat selection of Little Bustard males might be explained by the low overlap between their snort call frequency and that of traffic noise, but it also suggests a poor capacity by this bird to cope with recent, anthropogenic disturbance. In this respect, noisy but otherwise suitable habitats could be functioning as ecological traps for this rapidly declining species. - Martínez-Marivela, I., Morales, M.B., Iglesias-Merchán, C., Delgado, M.P., Tarjuelo, R. \& Traba, J. (2018). Traffic noise pollution does not influence habitat selection in the endangered Little Bustard. Ardeola, 65: 261-270.
\end{abstract}

Key words: disturbance, ecological trap, noise pollution, road traffic, Spain, steppe birds, Tetrax tetrax.

1 Terrestrial Ecology Group (TEG), Department of Ecology, Autónoma University of Madrid, E-28049 Madrid, Spain.

2 CENERIC Research Centre, Tres Cantos, Spain.

3 Department of Forest and Environmental Engineering and Management, Technical University of Madrid, Madrid, Spain.

4 Instituto de Investigación en Recursos Cinegéticos, IREC (CSIC, UCLM), Ronda de Toledo 12, 13071 Ciudad Real, Spain.

* Corresponding author: manuel.morales@uam.es 
RESUMEN.-El ruido del tráfico es un efecto asociado a la presencia de carreteras con un impacto potencialmente importante sobre la fauna. En el caso de las aves, puede alterar la distribución espacial de los individuos, su comportamiento y su condición fisiológica, con frecuencia enmascarando las señales emitidas por coespecíficos y depredadores. Analizamos cómo el ruido del tráfico rodado afecta a la selección de hábitat de los machos de sisón común durante la época reproductora, cuando emiten su breve canto territorial. El área de estudio se enmarca en el paisaje agrario típico del centro de España y está notablemente afectada por el ruido del tráfico rodado. Se elaboró un mapa de ruido usando un programa específico para el modelado del ruido ambiental. A partir de los niveles de ruido proporcionados por este modelo, el sustrato agrario y la distancia al vecino más cercano, se caracterizó el hábitat ocupado por 26 machos territoriales de sisón común (el 62\% de la población local) individualmente identificados. Se empleó el algoritmo MaxEnt para elaborar modelos de selección de hábitat para los machos de sisón, obteniendo un promedio de los 20 primeros modelos significativos. El mapa de ruido reveló niveles elevados de contaminación sonora en toda el área de estudio (rango 50,13-62,35dB). La distancia al macho más cercano fue la variable con mayor importancia en los modelos, de forma que la adecuación del hábitat disminuyó a medida que esa distancia aumentaba, mientras que el peso del ruido ambiental fue marginal. Esta falta de efecto del ruido del tráfico en la selección de hábitat de los machos de sisón común podría ser explicada por el reducido solapamiento del rango de frecuencia sonora de su canto con el del ruido, pero también sugiere una escasa capacidad en esta especie para adaptarse a una perturbación de origen antrópico reciente. En este contexto, hábitats ruidosos, pero, por lo demás, adecuados podrían funcionar como trampas ecológicas para esta especie amenazada en rápido declive. - Martínez-Marivela, I., Morales, M.B., Iglesias-Merchán, C., Delgado, M.P., Tarjuelo, R. y Traba, J. (2018). La contaminación sonora debida al tráfico rodado no influye en la selección de hábitat del sisón común. Ardeola, 65: 261-270.

Palabras clave: aves esteparias, contaminación sonora, España, perturbación, Tetrax tetrax, tráfico rodado, trampa ecológica.

\section{INTRODUCTION}

The effects of roads on terrestrial wildlife are widespread and well known (BenítezLópez et al., 2010; van der Ree et al., 2015). In the case of birds, many studies have shown that occurrence and abundance are often reduced near roads due to traffic disturbance or direct road mortality (Bautista et al., 2004; Fahrig \& Rytwinski, 2009; Summers et al., 2011; Torres et al., 2011). In particular, traffic noise exerts important negative effects on birds (Reijnen et al., 1995; Fahrig \& Rytwinski, 2009; Goodwin \& Shriver, 2011; see however Long et al., 2017) due to their general dependence on acoustic communication when breeding (Rheindt, 2003; Summers et al., 2011).

Habitat features strongly influence the transmission of acoustic signals and act as a selective pressure that shapes the evolution of bird songs (Seddon, 2005; Slabbekoorn et al., 2007). Likewise, ambient noise may interfere in signal transmission and individuals may respond to impaired communication by changing their habitat use (Slabbekoorn \& Smith, 2002; Rheindt, 2003; Goodwin \& Shriver, 2011). Anthropogenic noise occurs mostly in low-frequency bands below $2,000 \mathrm{~Hz}$ (Warren et al., 2006), and very often shows temporal patterns unusual in nature, which may hamper behavioural adaptive responses. Despite the strong link between habitat features and acoustic communication, studies on how anthropogenic noise modifies bird space use and habitat selection are still scarce and provide mixed results, with some species avoiding noisy areas, while others are unresponsive or even more abundant in noisier environments (Peris \& Pescador, 2004; Bayne 
et al., 2008; Goodwin \& Shriver, 2011). This issue is worthy of research attention because noisy but otherwise suitable habitats could be functioning as ecological traps (Gilroy \& Sutherland, 2007) if they compromise individual survival or reproductive success, which would be particularly deleterious in species of conservation concern.

The Little Bustard Tetrax tetrax is an endangered Palearctic steppe bird, currently listed as 'Near Threatened' globally and 'Vulnerable' in Europe (IUCN, 2012; BirdLife International, 2016). It is declining rapidly despite of the abundant research attention it has recently received (Morales \& Traba, 2016; García de la Morena et al., 2017). It occupies extensive cereal farmland, pastureland and natural steppes (Cramp \& Simmons, 1980; Morales et al., 2005; Faria et al., 2012). In Western Europe, Little Bustards inhabit mosaic-like agricultural landscapes with complementary resources (Morales et al., 2005), and exhibit a clear preference for semi-permanent agricultural substrates, such as fallows, pastures and field margins, as breeding habitats (Morales et al., 2005; Delgado et al., 2010; Faria et al., 2012). Breeding males display in exploded leks where they defend mating territories, which tend to aggregate due to conspecific attraction (Jiguet $e t$ al., 2000). The sexual display comprises a series of snort calls and jumps accompanied by wing-flapping, the wings making a characteristic whistle produced by emarginated 7th primary feathers (Jiguet \& Bretagnolle, 2001). Snort calls are mainly a territorial signal (Jiguet \& Bretagnolle, 2001), although they may also play a role in female attraction (Morales et al., 2014). Breeding Little Bustards tend to avoid infrastructures (SuárezSeoane et al., 2002, 2008) but no study has so far addressed how they distribute themselves in response to traffic noise. By excluding associated impacts such as traffic noise from habitat selection studies, we could be underestimating the real impact of infrastructures on threatened species. Here, we analyse the effect of road traffic noise on habitat selection by male Little Bustards. Given their mentioned tendency to avoid roads, we predict that males will also tend to avoid areas with higher noise levels.

\section{MethodS}

The study area (Figure 1A) is located in Campo Real (central Spain, $40^{\circ} 19^{\prime} \mathrm{N}, 3^{\circ} 18^{\prime} \mathrm{W}$, 800 m.a.s.l., 1600 ha). It is an Important Bird Area (IBA n. 75), and a hotspot for steppe birds in Spain (Traba et al., 2007) that is crossed by three Regional roads. With some interannual variation, approximately $72 \%$ of its surface is dedicated to farmland, mainly cereal and legume crops (47\%), ploughed fields $(18 \%)$, fallows and wastelands $(20 \%)$ and, to a much smaller extent vineyards, orchards and buildings.

Fieldwork was conducted during April and May 2012, coinciding with the mating activity peak of Little Bustard males (Cramp $\&$ Simmons, 1980). During 11 visits to the study site 26 different males were identified as individuals according to their plumage patterns (Arroyo \& Bretagnolle, 1999). These represented $62 \%$ of the maximum number of males counted that year in that population $(\mathrm{N}=42$ males). This procedure allowed us to choose those males with well-established territories in the study site in order to analyse the effects of habitat type and traffic noise on territory settlement while avoiding pseudoreplication.

A spatial noise model was built (see below) in order to investigate the influence of traffic noise on space use by Little Bustard males. Noise mapping and modelling software allows to estimate sound pressure levels over ground due to different noise sources, while also taking into account a variety of environmental and topographical parameters according to official standards and recom- 
A

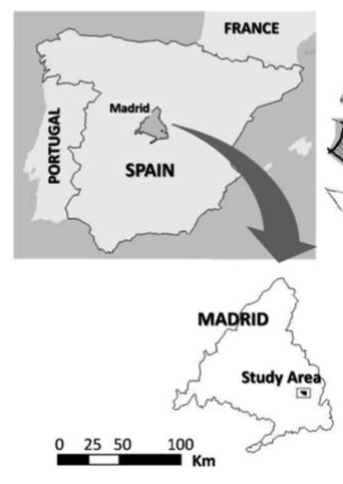

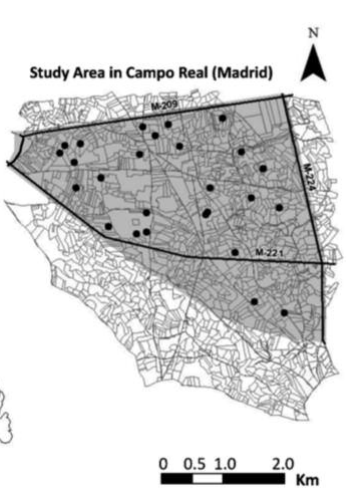

B

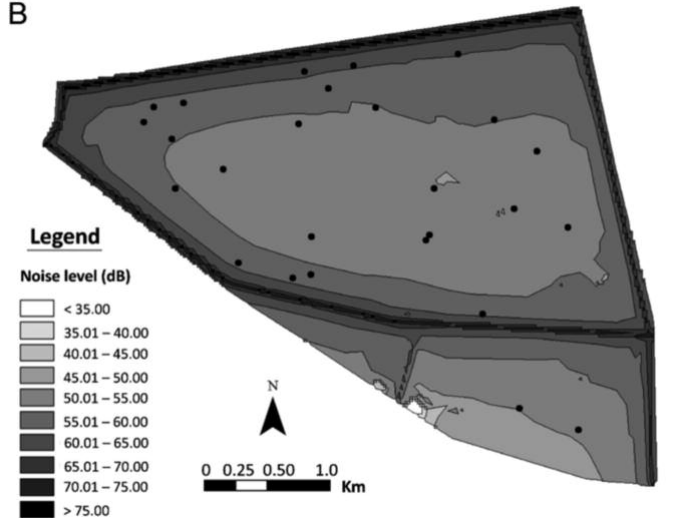

FIG. 1.-A. Geographical location of the study area, showing agricultural field limits. The shaded area represents the area included in the noise map. Roads M-209, M-221 and M-224 are also represented. B. Noise map of the study area. Noise was classified in $5 \mathrm{~dB}$ categories, for easier visualisation. Black dots in A and B represent individually identified Little Bustard males.

[A. Localización geográfica del área de estudio y mapa de parcelas agrarias de la misma. El área sombreada representa el área incluida en el mapa de ruido. Se representan igualmente las carreteras M-209, M-221 y M-224. B. Mapa de ruido del área de estudio. El ruido se ha clasificado en clases de $5 d B$ para una mejor representación. Los puntos negros en $A$ y $B$ representan los machos de sisón común individualmente identificados.]

mendations (Murphy \& King, 2010; Iglesias Merchan \& Diaz-Balteiro, 2013). The Noise model was elaborated according to the $\mathrm{Na}$ tional French Calculation Method 'NMPBRoutes-2008', recommended by the 2002/ 49/EU Directive on environmental noise assessment and management in order to evaluate traffic noise in the European Union (Dutilleux et al., 2010). Calculations were carried out with the software Predictor Type 7810, version 8.13 (Brüel \& Kjaer, 2011).

Information required for the noise model included the digital elevation model, which was based on official 1:5000 scale topographic digital maps (5 m contour lines) from the Regional Cartography Service. Official traffic data (traffic volume, hourly distribution, percentage of heavy vehicles, etc.) from the study area roads were provided by Madrid Regional Department of Transportation. In relation to vehicle speed, official traffic sampling stations provided realistic speed data for two roads only, since the third station was located in a low-speed road section (i.e. just after a crossroads), and thus data for that road were not representative. Therefore, we measured average speed along the third road by driving our own car at a similar speed to other road users and recording this on our own speedometer. Our estimate was very close to official measurements for the other two roads $(90 \mathrm{~km} / \mathrm{h}$ vs. $94 \mathrm{~km} / \mathrm{h}$ and $108 \mathrm{~km} / \mathrm{h}$ for official data). We also considered pavement type and standard meteorological conditions at the study area. For this purpose, traffic data from 07:00 to 10:00, the activity peak period of Little Bustard males (Martínez, 2016), were used to estimate the equivalent continuous sound pressure level $(\mathrm{dB})$.

The noise map of the study site (Figure 1A) was generated using a $50 \mathrm{~m}$ resolution grid of potential receiver points virtually located at a calculation height of $1 \mathrm{~m}$ above the ground level $(5,562$ receiver points within the study 
area). Sound pressure level at this resolution was used as an explanatory variable in habitat selection analysis.

MaxEnt software (Phillips et al., 2006) was used to analyse the influence of traffic noise and land use types on the spatial distribution of Little Bustard males. We chose this approach because it only requires presence data and performs well with small datasets (Phillips et al., 2006; Wisz et al., 2008). We employed as environmental predictors the cover of the different land uses, noise level, and conspecific presence, in the form of raster files with a $100 \times 100 \mathrm{~m}$ grid. Land use cover was extracted from a land use map for the study year updated during field visits. We built a raster grid for each of the following land uses: fallows, herbaceous crops, leguminous crops, ploughed land, unproductive land, unpaved tracks and lanes (hereafter tracks), woodlands and woody crops. Each cell of the raster grid represents the proportion of the considered land use within this cell. A noise level raster was calculated from the $50 \mathrm{~m}$ resolution noise model, assigning the average noise level within each $100 \mathrm{~m}$ raster cell. Finally, we built a raster based on distances to other males in order to incorporate in the model the effect of conspecific attraction, whose relevance has been shown in previous space use studies (e.g. Tarjuelo et al., 2013). To do so, we considered the distance of each male to $25 \%$ of all other mapped males, a significant proportion of the total sample. Thereby, for each cell, we assigned the average value of Euclidean distances from its centre to the six nearest males.

In order to evaluate the influence of each environmental variable, we followed a model averaging procedure. MaxEnt models were built until we obtained 20 statistically significant ones (according to one-tailed binomial tests, see below). For each MaxEnt model we used a cross-validation procedure, so that $75 \%$ of presence data were randomly selected to calibrate the model while the re- maining $25 \%$ were used to validate it. Regularisation parameters were automatically selected by the program in order to avoid overfitting (Elith et al., 2011). The generated probability maps were transformed into Boolean maps of presence/absence by using a probability threshold. We chose the average suitability approach (Cramer, 2003), which fixes the threshold at the mean of all cell values predicted by models built with the calibration dataset. This approach was chosen because it does not require true absence data and because of its effectiveness and simplicity (Liu et al., 2005). Cells below the threshold value were classified as absence and otherwise as presence.

Models were evaluated by looking at their significance and performance (Peterson et al., 2011). Model significance was evaluated by performing one-tailed binomial tests, in order to determine if the proportion of observations classified as presences differed from the proportion of area predicted as favourable by the model (Anderson et al., 2002; Peterson et al., 2011; Tarjuelo et al., 2014). Model performance was measured by the omission error rate (the proportion of presence records from the evaluation dataset that falls in areas predicted as unsuitable by the model). Low values of omission error rate indicate robust predictive models (Peterson et al., 2011; Tarjuelo et al., 2014). The average contribution of each variable was calculated from the 20 selected models and an average response curve for each environmental predictor was also obtained.

\section{RESULTS}

The flat terrain of the study area facilitates the propagation of traffic noise levels over the whole site. In fact, all locations of individually-recognisable Little Bustard males turned out to be exposed to road traffic noise levels higher than $50 \mathrm{~dB}$ during the moni- 
toring period (Figure 1B). Average sound pressure levels due to road traffic in breeding male territories varied between 50.13 and $62.35 \mathrm{~dB}$.

Habitat use models predicted a high percentage of the whole area as suitable for the Little Bustard (mean $\pm \mathrm{SD}=42.55 \pm 2.93$ ). Predictive power was high for all the models, with very low values of omission error rates (mean $\pm \mathrm{SD}=0.08 \pm 0.09$ ).

The variable that contributed the most to model building was distance to other males (54.55\% - Figure 2). This variable had a negative effect, meaning that as the distance to other males increased, the probability of presence decreased: this effect was particularly pronounced between $250 \mathrm{~m}$ and $600 \mathrm{~m}$ (Figure 3 ). The contribution of other variables was below 20\% (Figure 2). Presence of tracks

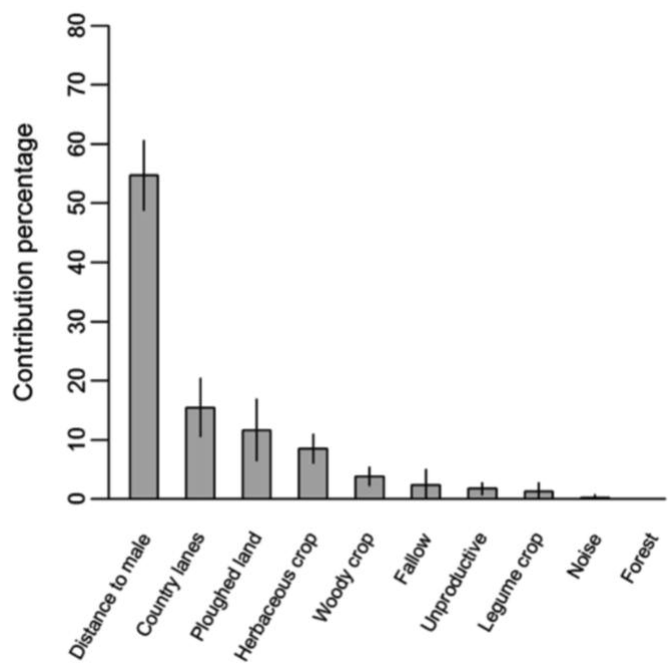

FIG. 2.-Average contribution percentages (mean $\pm \mathrm{SD}$ ) of each environmental variable to the MaxEnt models of Little Bustard male habitat selection (the variable "Country lanes" includes tracks and roads).

[Media de los porcentajes de contribución de cada variable ambiental a los modelos MaxEnt de selección de hábitat de machos de sisón común (la variable "Country lanes" incluye carreteras).] was the second most important variable, with a clear negative effect on predicting Little Bustard occurrence in the landscape (Figure 3). Cover of both herbaceous crops and ploughed land contributed similarly to the average habitat use model, although their response curves were mainly monotonic. The influence of noise in explaining habitat selection by Little Bustard males was negligible (Figure 2).

\section{DISCUSSION}

Estimated noise levels in most of the study area exceeded $40 \mathrm{~dB}$ (range 35-65 dB, Figure 1B), which is higher than the noise level considered typical for pastures and agricultural land (30 dB, Forman et al., 2002, Barber et al., 2009). Despite this and contrary to our expectation, the results show a negligible effect of traffic noise on the habitat selection of Little Bustard males. Our MaxEnt average model was consistent with existing knowledge of habitat selection by this species (Morales et al., 2005; Delgado et al., 2010; Tarjuelo et al., 2014) and highlights the great importance that conspecifics have on the spatial distribution and habitat use by Little Bustard males, even masking the influence of other relevant environmental predictors (see Devocoux et al., 2018 for a similar result). The probability of Little Bustard male presence decreases abruptly as the distance to the nearest neighbour increases. This spatial distribution is likely due to the species' exploded lek mating system (Jiguet et al., 2000), in which males distribute in a loosely aggregated manner (see for example Höglund \& Alatalo, 1995). Little Bustard males tend to locate their territories close to each other, interacting through calls and chases in order to defend their territories (Morales et al., 2014).

The presence of tracks also influences the spatial distribution of Little Bustard males (Suárez-Seoane et al., 2002, 2008). These 

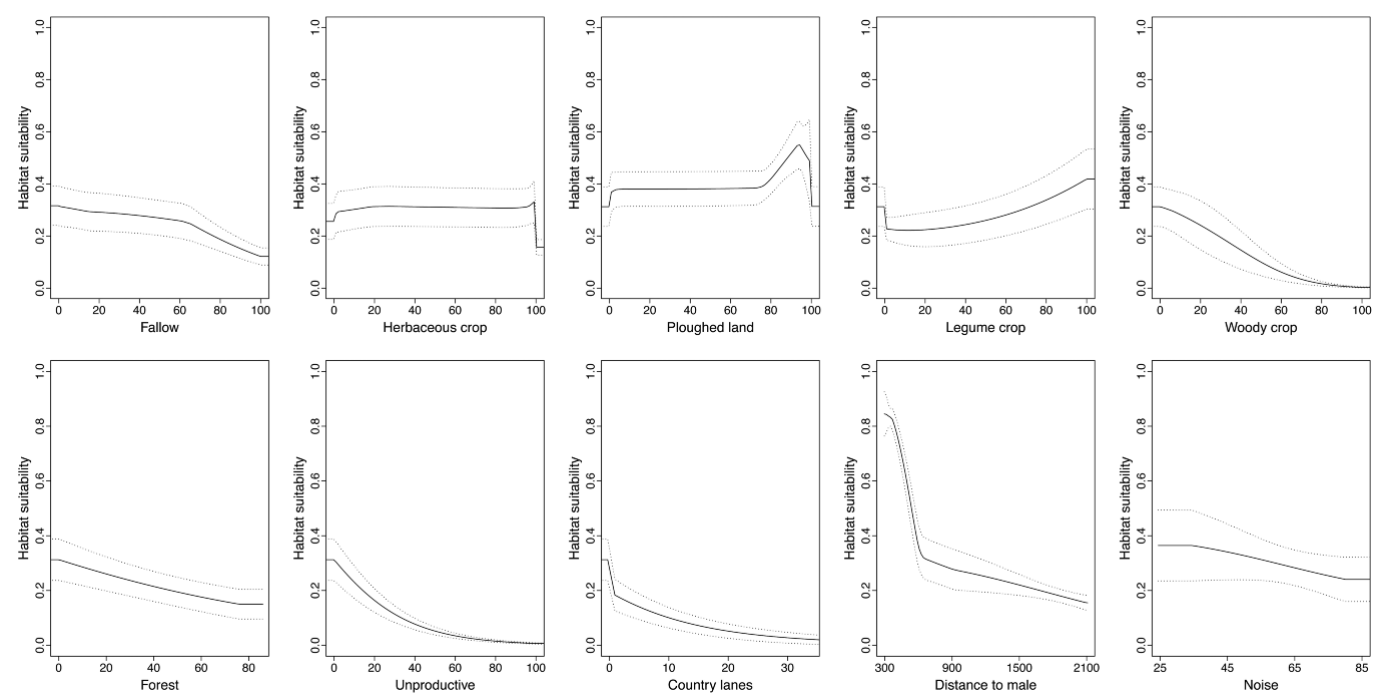

FIG. 3.-Average response curve for all the environmental variables used in the MaxEnt modelling to predict habitat suitability for Little Bustard males. Solid lines represent the predicted averaged values and broken lines the standard deviation (the variable "Country lanes" includes tracks and roads).

[Curvas de respuesta promedio para las variables ambientales empleadas en los modelos MaxEnt de selección de hábitat de machos de sisón común. Las líneas contínuas indican los valores promedios predichos y las discontínuas la desviación estándar (la variable "Country lanes" incluye las carreteras).]

might be a source of disturbance because they are used by farmers and people engaged in leisure activities (Tarjuelo et al., 2015).

Traffic noise can affect the distribution of bird species (Goodwin \& Shriver, 2011) and may be an important selective pressure (Seddon, 2005). However, we could not find a clear effect of traffic noise on the habitat selection and spatial distribution of Little Bustard males during the breeding season. This lack of response has also been described for other bird species in different habitats (Peris \& Pescador, 2004; Goodwin \& Shriver, 2011). The latter authors found that, among species of North American temperate forests, those whose song frequency range was within the low frequency range of road traffic noise avoided noisy areas, while those whose song frequency range did not overlap with that of traffic noise or did so only partially (i.e. they reached higher frequencies) did not respond to it, and their distribution was exclusively explained by habitat variables (Goodwin \& Shriver, 2011). The Little Bustard snort call frequency ranges from 1,500 to $9,000 \mathrm{~Hz}$ (Xeno-canto, 2017, http://www.xeno-canto.org/ species/Tetrax-tetrax?view $=3$ ), while traffic noise frequency in our study area was 2,000$3,500 \mathrm{~Hz}$ (own unpubl. data). Thus, the male territorial call would be masked only to a small degree by traffic noise and this could explain its negligible effect on habitat selection compared to other variables (Goodwin \& Shriver, 2011).

Nevertheless, the Little Bustard is a nonsong bird whose male call is acoustically simple (Jiguet \& Bretagnolle, 2001) and thus might lack the flexibility to respond adaptively to the historically recent traffic noise disturbance. If traffic noise reduces the efficiency of snort calls as territorial and/or mating signals in any way, males would face 
potential fitness costs. In those circumstances, noisy but otherwise suitable habitats would be functioning as ecological traps (Gilroy \& Sutherland, 2007). Hence, whether Little Bustard males respond to traffic noise through changes in the acoustic traits of their snort calls is a possibility that should be explored in future studies.

ACKNOWLEDGEMENTS.-Funding was provided by the Spanish Ministry of Science (CGL200913029/BOS); and the networks of the Madrid region REMEDINAL2 (S-2009/AMB/1783) and REMEDINAL 3CM (S2013/MAE-2719). RT was supported by a postdoctoral fellowship funded by REMEDINAL3 (S2013/MAE-2719). We thank Miguel Pérez-Galdós, Harald Aagesen and Douglas Manwell for technical support, and two anonymous reviewers for their valuable comments.

Author CONTRIBUtions. - JT and MBM conceived and designed the study. IMM and MPD collected data and built the GIS project. CIM computed the noise model and helped in data analyses. IMM and RT analyzed data. RT and MBM wrote the current version of the ms. JT, MBM and RT revised the ms at different stages.

\section{REFERENCES}

Anderson, R.P., Gómez-Laverde, M. \& Peterson, A.T. (2002). Geographical distributions of spiny pocket mice in South America: Insights from predictive models. Global Ecology and Biogeography, 11: 131-141.

Arroyo, B. \& Bretagnolle, V. (1999). Field identification of individual Little Bustard Tetrax tetrax males using plumage patterns. Ardeola, 46: 53-60.

Barber, J.R., Crooks, K.R. \& Fristrup, K.M. (2009). The costs of chronic noise exposure for terrestrial organisms. Trends in Ecology and Evolution, 25: 180-189.

Bautista, L.M., García, J.T., Calmaestra, R.G., Palacin, C., Martín, C.A., Morales, M.B., Bonal, R. \& Viñuela, J. (2004). Effect of weekend road traffic on the use of space by raptors. Conservation Biology, 18: 726-732.

Benítez-López, A., Alkemade, R. \& Verweij, P.A. (2010). The impact of roads and other infrastructure on mammal and bird populations: a meta-analysis. Biological Conservation, 143: 1307-1316.

BirdLife International. (2016). Species factsheet: Tetrax tetrax. Downloaded from http://www. birdlife.org on 21/07/2016

Brüel \& Kjær (2011). Technical documentation predictor type 7810. Version 8.13. User manual. Brüel \& Kjær Sound \& Vibration Measurement A/S. Naerum, DK.

Cramer, J.S. (2003). Logit models: from economics and other fields. Cambridge University Press. Cambridge.

Cramp, S. \& Simmons, K.E.L (1980). The birds of the Western Paleartic. Vol II. Oxford University Press. Oxford.

Delgado, M.P., Traba, J., García de la Morena, E.L. \& Morales, M.B. (2010). Habitat selection and density-dependent relationships in spatial occupancy by male Little Bustards Tetrax tetrax. Ardea, 98: 185-194.

Devoucoux, P., Besnard, A. \& Bretagnolle, V. (2018). Sex-dependent habitat selection in a high-density Little Bustard Tetrax tetrax population in southern France, and the implications for conservation. Ibis, in press (doi: 10.1111/ ibi.12606).

Dutilleux, G, Defrance, J., Ecotière, D. \& Le Duc, E. (2010). NMPB-Routes-2008: The revision of the french method for road traffic noise prediction. Acta Acustica united with Acustica, 96: 452-462.

Elith, J., Phillips, S.J., Hastie, T., Dudík, M., Chee, Y.E. \& Yates, C.J. (2011). A statistical explanation of MaxEnt for ecologists. Diversity and Distributions, 17: 43-57.

Fahrig, L. \& Rytwinski, T. (2009). Effects of roads on animal abundance: an empirical review and synthesis. Ecology and Society, 14: 21.

Faria, N., Rabaça, J.E. \& Morales, M.B. (2012). The importance of grazing regime in the provision of breeding habitat for grassland birds: The case of the endangered little bustard (Tetrax tetrax). Journal for Nature Conservation, 20: 211-218.

Forman, R.T.T., Reineking, B. \& Hersperger, A.M. (2002). Road traffic and nearby grassland 
bird patterns in a suburbanizing landscape. Environmental Management, 29: 782-800.

García de la Morena, E.L., Bota, G., Mañosa, S. \& Morales, M.B. (2017). II Censo Nacional de Sisón Común: el dramático declive del bastión europeo de la especie. In, SEO/BirdLife: Programas de seguimiento y grupos de trabajo de SEO/BirdLife 2016, pp. 4-11. SEO/BirdLife, Madrid.

Gilroy, J.J. \& Sutherland, W.J. (2007). Beyond ecological traps: perceptual errors and undervalued resources. Trends in Ecology and Evolution, 22: 351-356.

Goodwin, S.E. \& Shriver, W.G. (2011). Effects of traffic noise on occupancy patterns of forest birds. Conservation Biology, 25: 406-411.

Höglund, J. \& Alatalo, R.V. (1995). Leks. Princeton University Press. Princeton.

Iglesias, C., Mata, C. \& Malo, J.E. (2012). The influence of traffic noise on vertebrate road crossing through underpasses. Ambio, 41: 193-201.

Iglesias Merchan, C. \& Diaz-Balteiro, L. (2013). Noise pollution mapping approach and accuracy on landscape scales. Science of the Total Environment, 449: 115-125.

IUCN. (2012). IUCN Red List of Threatened Species. Version 2012.2. www.iucnredlist.org. Accessed 27/05/2013.

Jiguet, F., Arroyo, B. \& Bretagnolle, V. (2000). Lek mating systems: a case study in the Little Bustard. Behavioural Processes, 51: 63-82.

Jiguet, F. \& Bretagnolle, V. (2001). Courtship behaviour in a lekking species: Individual variations and settlement tactics in male little bustard. Behavioural Processes, 55: 107-118.

Liu, C., Berry, P.M., Dawson, T.P. \& Pearson, R.G. (2005). Selecting thresholds of occurrence in the prediction of species distributions. Ecography, 28: 385-393.

Long, A.M., Colón, M.R., Bosman, J.L., Robinson, D.H., Pruett, H.L., McFarland, T.M., Mathewson, H.A., Szewczak, J.M., Newman, J.C. \& Morrison, M.L. (2017). A before-after control-impact assesment to understand the potental impacts of highway construction noise and activity on an endangered songbird. Ecology \& Evolution, 7: 379-389.

Martínez, C. (2016). Sisón común - Tetrax tetrax. In, Salvador, A. \& Morales, M.B. (Eds.): Enciclopedia Virtual de los Vertebrados Españoles. Museo Nacional de Ciencias Naturales,
Madrid. http://www.vertebradosibericos.org/ Accessed 20/12/2017.

Morales, M.B., García, J.T. \& Arroyo, B. (2005). Can landscape composition changes predict spatial and annual variation of little bustard male abundance? Animal Conservation, 8: 167-174. Morales, M.B., Casas, F., García de la Morena, E.L., Ponjoan, A., Calabuig, G., MartínezPadilla, J., García, J.T., Mañosa, S., Viñuela, J. \& Bota, G. (2014). Density dependence and habitat quality modulate the intensity of display territory defence in an exploded lekking species. Behavioral Ecology and Sociobiology, 68: 1493-1504.

Morales, M.B. \& Traba, J. (2016). Prioritising research in steppe bird conservation: a literature survey. Ardeola, 63: 137-150.

Murphy, E. \& King, E.A. (2010). Strategic environmental noise mapping: Methodological issues concerning the implementation of the EU Environmental Noise Directive and their policy implications. Environment International, 36: 290-298.

Peterson, A.T., Soberón, J., Pearson, R.G., Anderson, R.P., Martínez-Meyer, E., Nakamura, M. \& Bastos Araújo, M. (2011). Ecological niches and geographic distributions. Princeton University Press. Princeton.

Phillips, S.J., Anderson, R.P. \& Schapire, R.E. (2006). Maximum entropy modeling of species geographic distributions. Ecological Modelling, 190: 231-259.

van der Ree, R., Smith, D.J. \& Grilo, C. (2015). Handbook of road ecology. John Wiley \& Sons. Reijnen, R., Foppen, R., Ter Braak, C. \& Thissen, J. (1995). The effects of car traffic on breeding bird populations in woodland. III. Reduction of density in relation to the proximity of main roads. Journal of Applied Ecology, 32: 187-202.

Rheindt, F.E. (2003). The impact of roads on birds: Does song frequency play a role in determining susceptibility to noise pollution? Journal of Ornithology, 144: 295-306.

Seddon, N. (2005). Ecological adaptation and species recognition drives vocal evolution in Neotropical suboscine birds. Evolution, 59: 200-215.

Slabbekoorn, H. \& Smith, T.B. (2002). Habitatdependent song divergence in the little greenbul: an analysis of environmental selection pressures on acoustic signals. Evolution, 56: 1849-1858. 
Slabbekoorn, H., Yeh, P. \& Hunt, K. (2007). Sound transmission and song divergence: a comparison of urban and forest acoustics. The Condor, 109: 67-78.

Suárez-Seoane, S., Osborne, P.E. \& Alonso, J.C. (2002). Large-scale habitat selection by agricultural steppe birds in Spain: identifying species-habitat responses using generalized additive models. Journal of Applied Ecology, 39: 755-771.

Suárez-Seoane, S. García de la Morena, E.L., Morales, M.B., Osborne, P.E. \& de Juana, E. (2008). Maximum entropy niche-based modelling of seasonal changes in little bustard (Tetrax tetrax) distribution. Ecological Modelling, 219: 17-29.

Summers, P.D., Cunnington, G.M. \& Fahrig, L. (2011). Are the negative effects of roads on breeding birds caused by traffic noise? Journal of Applied Ecology, 48: 1527-1534.

Tarjuelo, R., Delgado, M.P., Bota, G., Morales, M.B., Traba, J., Ponjoan, A., Hervás, I. \& Mañosa, S. (2013). Not only habitat but also sex: Factors affecting spatial distribution of Little Bustard Tetrax tetrax families. Acta Ornithologica, 48: 119-128.

Tarjuelo, R., Morales, M.B., Traba, J. \& Delgado, M.P. (2014). Are species coexistence areas a good option for conservation management? Applications from fine scale modelling in two steppe birds. PLoS One, 9: e87847.

Tarjuelo, R., Barja, I., Morales, M.B., Traba, J., Benítez-López, A., Casas, F., Arroyo, B., Delgado, P. \& Mougeot, F. (2015). Effects of human activity on physiological and behavioral responses of an endangered steppe bird. $B e$ havioral Ecology, 26: 828-838.

Torres, A., Palacín, C. Seoane, J. \& Alonso, J.C. (2011). Assessing the effects of a highway on a threatened species using Before-During-After and Before-During-After-Control-Impact designs. Biological Conservation, 144: 2223-2232.

Traba, J., García de la Morena, E.L., Morales, M.B. \& Suárez, F. (2007). Determining high value areas for steppe birds in Spain: hot spots, complementarity and the efficiency of protected areas. Biodiversity and Conservation, 16: 3255-3275. Warren, P.S., Katti, M., Ermann, M. \& Brazel, A. (2006). Urban bioacoustics: it's not just noise. Animal Behaviour, 71: 491-502.
Wisz, M.S., Hijmans, R.J., Li, J., Peterson, A.T., Graham, C.H., Guisan, A. \& NCEAS Predicting Species Distributions Working Group. (2008). Effects of sample size on the performance of species distribution models. Diversity and Distributions, 14: 763-773.

Xeno-Canto. (2017). http://www.xeno-canto.org/ species/Tetrax-tetrax?view=3. Accessed 20/12/ 2017.

\section{Supplementary Electronic Material}

Additional supporting information may be found in the on-line version of this paper. See volume 65(2) on www.ardeola.org

Table S1. Contribution percentage of variables included MaxEnt in models of Little Bustard habitat selection.

Submitted: December 25, 2017 Minor revision: February 28, 2018 Second version arrives: March 25, 2018 Accepted: March 28, 2018

Editor: Beatriz Arroyo

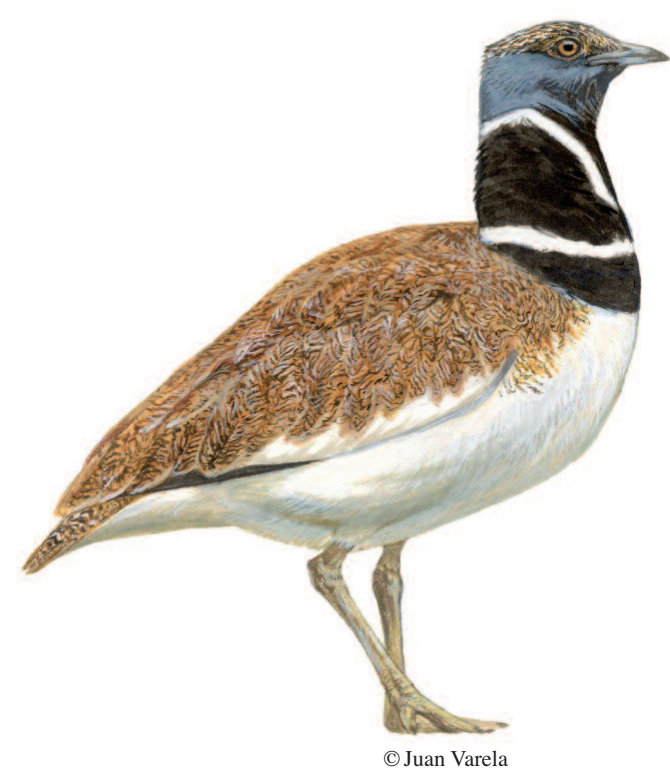

